\begin{tabular}{|c|c|c|}
\hline & Int.J.Curr.Microbiol.App.Sci (2021) 10(08): 414-420 & \\
\hline & $\begin{array}{l}\text { International Journal of Current Microbiology and Applied Sciences } \\
\text { ISSN: 2319-7706 Volume } 10 \text { Number } 08 \text { (2021) } \\
\text { Journal homepage: http://www.ijcmas.com }\end{array}$ & 80,8 \\
\hline $\begin{array}{l}\text { EXCELLENT } \\
\text { PUBLISHERS }\end{array}$ & & muwijicmascom \\
\hline
\end{tabular}

Original Research Article

https://doi.org/10.20546/ijcmas.2021.1008.050

\title{
An Evaluation of Treated Effluent Quality of Dairy Industry in Hanumangarh, Rajasthan, India
}

\author{
Rinku Chawla* and Atul Arora
}

Department of Science, Tantia University, Sri Ganganagar, Rajasthan, India

*Corresponding author

\section{Keywords}

Effluent treatment plant, irrigation water quality, dairy industry, treated water, environment pollution, corrosive indices

Article Info

Accepted:

20 July 2021

Available Online:

10 August 2021

\section{A B S T R A C T}

The present study aims to evaluate treated effluent quality of the dairy industry in terms of irrigation water quality parameters, environment pollution and corrosion potential of treated water. For this, various physicochemical parameters were measured twice a month following standard methods for one year from February 2020 to January 2021. Irrigation water quality parameters - SAR, PSS, ESP, RSC, EC, TDS were evaluated to find the suitability of study area treated water used for watering gardens in industry area. The results revealed that average value of SAR, PSS, ESP and RSC was 3.158, 59.44\%, 3.285, and 0.248 respectively. Average value of organic pollution parameters BOD (29.19) and COD (56.48) are within permissible limits(IS-2296, 1982). Calculated average values of LSI (0.427) and AI (12.42) indicated non-aggressive nature of the treated effluent with slight scales to slight corrosion. These results are likely to address wastewater compliance issues related to irrigation and other reuse purposes.

\section{Introduction}

Dairy plants are the centre where raw milk is processed either for direct consumption or converted into other dairy products like butter, cheese, ghee, whey, milk powder etc. India is the world's largest milk producer with more than $13 \%$ of world's total milk and consumes almost $100 \%$ of its own milk production. Dairy plants are generally called 'wet industry', as they consume large volume of water for diverse purposes. Water is key processing medium in dairy industry. It is used for various processes like heating, cooling, sanitization, cleaning, floor washing etc. As a result, dairy industry generates huge volume of wastewater and is primarily a source of organic pollution. It generates about 0.2 to 10 liter of effluent per liter of milk processed depending on the processing products. It is 
estimated that about $2 \%$ of the total milk processed in plants is wasted into drains. The major contaminants in dairy wastewater are milk solids that include milk fat, proteins, lactose and lactic acid. Minor constituents include sodium, potassium, calcium and chloride (EPA, 1997). Proper treatment of effluent is of utmost importance as high organic loads of dairy effluents degrade rapidly and deplete the DO level of receiving streams, becoming propagation place for mosquitoes and flies. So, it is needed to provide required treatment before discharge into environment.

Effective treatment expects a proper planning of treatment plants units should be characterized from time to time. Findings of present research work on study of treated dairy effluent quality may become very useful for this industry to plan proper disposal, recycling and utilization strategy so as to keep the environment clean and pollution free.

The main objective of present work is to study the behavior of various quality parameters of dairy waste water. Characterization of treated effluent was evaluated in terms of irrigation water quality, pollution indicators, corrosively of water and compared with standard values to determine its reuse suitability. It will help to monitor the overall performance of effluent treatment plant and to address the waste water compliance issue with reference to irrigation and other uses.

\section{Materials and Methods}

\section{Area of Study}

SARAS is famous and leading milk and milk product brand in Rajasthan. Effluent treatment plants are installed in industries to meet regulating norms governed by pollution control boards. The ETP of SARAS dairy, Sri Ganganagar Zila Dugdh Utpadak Sehkari
Sangh Ltd. Hanumangarh having capacity to treat $500 \mathrm{~m}^{3}$ per day of effluent was selected for present study.

\section{ETP: An overview}

Activated sludge system with fixed type surface aerator is designed to handle waste water with high organic content and suspended solids. Aerobic Biological Reactor works as heart of the system. Present setup of SARAS dairy states that its current milk collection is 100,000 liter per day with daily water requirement of 2 liter per liter of milk processed. The various processing units in industry are milk pasteurizing, cheese, Whey and milk powder etc. SARAS has boiler section with water softening provisions and all safety measures. Regular CIP (Cleaning inside procedure) is carried out to maintain healthy and clean environment.

\section{Physicochemical Analysis}

The secondary treated wastewater samples were collected from the ETP of SARAS dairy, Sri Ganganagar Zila Dugdh Utpadak Sehkari Sangh Ltd. Hanumangarh. The composite samples were collected quarterly in cleaned, washed and rinsed glass bottles for a period of one year from February,2020 to January, 2021. The collected samples were analyzed for various physico-chemical parameterstemperature, $\mathrm{pH}$, electrical conductance (EC), Chemical Oxygen Demand (COD), biological oxygen demand (BOD), total alkalinity (TA), total hardness $(\mathrm{TH})$, total dissolved solids (TDS), sodium $\left(\mathrm{Na}^{+}\right)$, potassium $\left(\mathrm{K}^{+}\right)$, calcium $\left(\mathrm{Ca}^{2+}\right)$, magnesium $\left(\mathrm{Mg}^{2+}\right)$, chloride $\left(\mathrm{Cl}^{-}\right)$, sulphate $\left(\mathrm{SO}_{4}{ }^{2-}\right)$, nitrate $\left(\mathrm{NO}_{3}{ }^{-}\right)$and fluoride $\left(\mathrm{F}^{-}\right)$as per standard methods. Temperature and $\mathrm{pH}$ were measured at the sampling site. DO fixation was performed at the location itself by adding manganese sulphate and alkaline KI solution and samples were stored at $4{ }^{\circ} \mathrm{C}$ for determining other parameters. For sampling 
and testing the procedure described in standard methods were adopted(APHA, IS$3025,1987)$. All the reagents used were AR grade and double distilled water was used for solution preparation.

\section{Data Analysis}

Data of measurement (Table -1) was used to enumerate calculated indices for water quality. Descriptive statistics - range, mean and coefficient of variation (CV) were applied using MS-Excel and results are presented in Table-3.

\section{Results and Discussion}

The treated effluent is mainly used in gardens of the dairy campus and eco-plantation. The quality of irrigation water is quite important for healthy flora and fauna. Extra Water may be discharged to surface water or reused in other industrial uses. The results of present study were analyzed from three aspects, viz: irrigation water quality, environment pollution indicators and corrosive potential.

\section{Irrigation Water Quality Index}

The suitability of given water body in terms of physicochemical parameters for irrigation is judged from sodium hazard and water salinity.

\section{Sodium Hazard}

Relative proportion of sodium to other cations like potassium, calcium, magnesium etc. is very important in irrigation water as the soil structure in considerably affected in the long run by the sodium content in the irrigation water. Cation exchange relationships of sodium with clay particles in the soil tend to breakdown the clay. Such dispersed soils have poor infiltration and permeability. To evaluate sodium hazard in the study area water, Sodium Adsorption Ratio (SAR), Percent Soluble
Sodium (PSS), Residual sodium carbonate (RSC) and Exchangeable Sodium Percentage (ESP) were calculated using the relations presented in Table- 2 .

Based on classification of irrigation water as per SAR values, the treated effluent from studied dairy ETP could be classified as low sodium hazard to soil(IS-11624, 1986). The SAR was found to be $3.158(\mathrm{me} / \mathrm{l})^{1 / 2}$ on average ranging from $2.678(\mathrm{me} / \mathrm{l})^{1 / 2}$ to $3.928(\mathrm{me} / \mathrm{l})^{1 / 2}$ with $\mathrm{CV}$ only $9.0 \%$. The PSS value was found $59.44 \%$ on average ranging from $56.18 \%$ to $65.32 \%$ with CV only $4.0 \%$ and is permissible for irrigation (FAO/UNESCO, 1973).

Residual sodium carbonate (RSC)is bicarbonate $\left(\mathrm{HCO}_{3}{ }^{-}\right)$and carbonate anions $\left(\mathrm{CO}_{3}{ }^{2-}\right)$ concentration, as it related to $\mathrm{Ca}^{2+}$ and $\mathrm{Mg}^{2+}$ ions. The RSC was found to be $0.248 \mathrm{me} / \mathrm{l}$ on average ranging from -0.029 me/l to $0.478 \mathrm{me} / \mathrm{l}$ with $\mathrm{CV} 49.0 \%$. Values of RSC less than 0.5 indicate that sodium buildup is unlikely since sufficient calcium and magnesium are in excess of that can be precipitated as carbonates. These values fall in the safe range of suitability of water for irrigation (Wilcox, et al., 1954).

Exchangeable Sodium Percentage (ESP): Three levels of exchangeable sodium percentage (ESP) which correspond to three tolerance levels are defined as: sensitive (ESP < 15), semi-tolerant (ESP 15-40) and tolerant (ESP > 40) (FAO, 1973, GA Pearson, 1960). The crops/plants listed as sensitive include, among others, beans, maize, peas, orange, peach, moong bean, gram and cowpea. Semi tolerant plans include carrot, clover, lettuce, barseem, oat, onion, radish, rye, sorghum, spinach, tomato and tolerant plants include alfalfa, barley, beet, Rohadesgrass and Karnal (Kallar) grass. The ESP was found to be 3.285 on average ranging from 2.620 to 4.338 with CV only $12.0 \%$. 


\section{Water Salinity}

Total Dissolved Solids (TDS) and Electrical Conductance (EC) contribute to water salinity. The main effect of TDS and EC of irrigation water on crop production is the inability of the plant to compete with ions and the soil solution for water. The higher the EC and TDS, the lesser water is available to plants even thought the field may appear wet. The EC value of study area varies from $670 \mu \mathrm{mhos} / \mathrm{cm}$ to $840 \mu \mathrm{mhos} / \mathrm{cm}$ with CV only $5.0 \%$ and average value of $741.5 \mu \mathrm{mhos} / \mathrm{cm}$. The EC values fall in medium range of salinity and are suitable in most cases with moderate range (R.S. Ayers and D.W. Westcot. 1994). TDS concentration in the treated effluent was found to vary from $210 \mathrm{mg} / \mathrm{l}$ to $354 \mathrm{mg} / \mathrm{l}$ with CV only $15.0 \%$ and average value of 272.8 $\mathrm{mg} / \mathrm{l}$. This value is below the Indian standard guidelines for irrigation water and usually has no detrimental effects. Kolhe et al., 2011, studied dairy industrial effluent and recorded TDS value, $1000 \mathrm{mg} / \mathrm{l}$ for untreated effluent and $480 \mathrm{mg} / \mathrm{l}$ for treated effluents.

\section{Specific Anions}

The anions measured to determine the irrigation water quality are Chloride, Sulphate, Nitrate and Fluoride. The values of chloride are in the range $37.0 \mathrm{mg} / \mathrm{l}$ to $50.0 \mathrm{mg} / \mathrm{l}$ with $\mathrm{CV}$ only $8.0 \%$ and average value of 43.47 $\mathrm{mg} / \mathrm{l}$ and are generally safe for all types of plants(TA Bauder et al., 2011). The sulphate values vary from 5.2 to 6.8 with $\mathrm{CV}$ only $8.0 \%$ and average value of $6.03 \mathrm{mg} / \mathrm{l}$. The nitrate values are in the range $0.8 \mathrm{mg} / \mathrm{l}$ to 1.8 $\mathrm{mg} / \mathrm{l}$ with CV only $20.0 \%$ and average value of $1.3 \mathrm{mg} / \mathrm{l}$. The fluoride concentrations are very low ranging from $0.11 \mathrm{mg} / \mathrm{l}$ to $0.2 \mathrm{mg} / \mathrm{l}$ with CV only $14.0 \%$ and average value 0.14 $\mathrm{mg} / \mathrm{l}$. All these anions are below the accepted and permissible values of irrigation water as per Indian Standards (IS-2296, 1982). The values of above discussed parameters signify that ETP is working efficiently and the treated effluent can be safely used for irrigation. Kolhe et al., 2011, recorded chloride and sulphate values $90 \mathrm{mg} / \mathrm{l}$ and $75 \mathrm{mg} / \mathrm{l}$ respectively in the treated dairy effluent.

\section{Environment Pollution Indicators}

COD and BOD values have been widely adopted as a measure of pollution effect. They are the most common measures of pollutant organic material in water in terms of relative oxygen-depletion effect of a waste contaminant. COD values of study area fall in the range of $45 \mathrm{mg} / \mathrm{l}$ to $84 \mathrm{mg} / \mathrm{l}$ with CV only $20.0 \%$ and average value of $56.48 \mathrm{mg} / \mathrm{l}$. BOD values of treated water vary from $22 \mathrm{mg} / \mathrm{l}$ to $44 \mathrm{mg} / \mathrm{l}$ with CV only $20.0 \%$ and average value of $29.19 \mathrm{mg} / \mathrm{l}$. These values are in permissible limit for irrigation water. Kolhe $e t$ al., 2011 recorded COD and BOD values 94 $\mathrm{mg} / \mathrm{l}$ and $28.55 \mathrm{mg} / \mathrm{l}$ respectively in the treated dairy effluent. The biodegradability of wastewater is determined from BOD/COD ratio. If the $\mathrm{BOD} / \mathrm{COD}$ ratio of the industrial effluent is more than 0.6 , it is biologically treatable. If the BOD/COD ratio is less than 0.3 biological treatment is not necessary (Chaudharyand Dhoble, 2010).This ratio for the study area varies from 0.469 to 0.561 to with an average value of 0.517 . It reflects effective biodegradation of organic compounds and hence effective treatment.

\section{Corrosive Indices}

To determine corrosion potential of treated water, corrosive indices LSI and AI are calculated. 
Table.1

Table - 1 Physico-chemical parameters for ETP Sri Ganganagar Zila Dugdh Utpadak Sehkari Sangh Ltd., Hanumangarh (Rajasthan)

\begin{tabular}{|c|c|c|c|c|c|c|c|c|c|c|c|c|c|c|c|c|c|c|c|}
\hline Sample & Month & Temp. & $\mathrm{pH}$ & EC & COD & BOD & TH & TA & TDS & $\mathrm{Na}^{+}$ & $\mathbf{K}^{+}$ & $\mathrm{Ca}^{+2}$ & $\mathrm{Mg}^{+2}$ & $\mathrm{NO}_{3}^{-}$ & $\mathrm{SO}_{4}^{-2}$ & $\mathrm{Cl}^{-}$ & $\mathbf{F}$ & $\mathrm{CO}_{3}{ }^{2-}$ & $\mathrm{HCO}_{3}$ \\
\hline EH1 & February (1) & 17.7 & 8.3 & 700 & 53 & 28.0 & 94 & 126 & 246 & 67 & 7.5 & 20.0 & 10.7 & 1.1 & 5.4 & 40 & 0.13 & 2 & 124 \\
\hline EH2 & February (2) & 18.2 & 8.4 & 726 & 57 & 32.0 & 90 & 128 & 218 & 72 & 7.1 & 19.2 & 10.2 & 1.2 & 5.5 & 42 & 0.11 & 2 & 126 \\
\hline EH3 & $\operatorname{March}(1)$ & 20.8 & 8.5 & 748 & 72 & 37.0 & 87 & 132 & 254 & 70 & 8.2 & 18.4 & 10.0 & 1.3 & 5.7 & 43 & 0.1 & 4 & 128 \\
\hline EH4 & $\operatorname{March}(2)$ & 22 & 8.6 & 760 & 77 & 40.0 & 102 & 144 & 286 & 74 & 6.0 & 21.6 & 11.7 & 1.4 & 6.2 & 47 & 0.14 & 6 & 138 \\
\hline EH5 & May (2) & 25.6 & 8.7 & 840 & 84 & 44.0 & 116 & 148 & 342 & 82 & 6.4 & 24.0 & 13.6 & 1.7 & 6.8 & 48 & 0.16 & 8 & 140 \\
\hline EH6 & June (1) & 27.8 & 8.8 & 800 & 70.4 & 36.0 & 110 & 140 & 316 & 78 & 7.5 & 23.2 & 12.6 & 1.4 & 6.3 & 47 & 0.15 & 4 & 136 \\
\hline EH7 & June (2) & 28.4 & 8.5 & 780 & 65 & 32.0 & 108 & 136 & 354 & 73 & 6.2 & 23.2 & 12.1 & 1.3 & 5.7 & 42 & 0.12 & 2 & 134 \\
\hline EH8 & July & 27.5 & 8.3 & 746 & 55.8 & 27.0 & 96 & 132 & 328 & 65 & 6.2 & 21.6 & 10.2 & 1.6 & 6.5 & 43 & 0.14 & 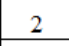 & 130 \\
\hline EH9 & July (2) & 26.4 & 7.9 & 730 & 48.6 & 24.0 & 90 & 128 & 282 & 62 & 6.0 & 18.4 & 10.7 & 1.8 & 6.7 & 45 & 0.17 & 0 & 128 \\
\hline EH10 & August (1) & 25 & 8 & 710 & 56.6 & 28.0 & 88 & 122 & 268 & 58 & 6.4 & 16.8 & 11.2 & 1.7 & 6.4 & 41 & 0.16 & 2 & 120 \\
\hline EH11 & August (2) & 24.8 & 8.1 & 738 & 60.2 & 32.0 & 92 & 128 & 295 & 64 & 6.4 & 19.2 & 10.7 & 1.4 & 6.2 & 40 & 0.15 & 4 & 124 \\
\hline EH12 & September (1) & 24.2 & 8.2 & 724 & 48.8 & 26.0 & 94 & 123 & 272 & 62 & 6.7 & 19.6 & 10.9 & 1.2 & 6 & 37 & 0.17 & 0 & 123 \\
\hline EH13 & September (2) & 23.2 & 8.3 & 684 & 50 & 28.0 & 97 & 130 & 250 & 71 & 6.8 & 22.0 & 10.2 & 1.1 & 5.8 & 44 & 0.16 & 2 & 128 \\
\hline EH14 & October (1) & 22.5 & 8.3 & 670 & 46.7 & 25.0 & 104 & 126 & 234 & 67 & 6.9 & 22.4 & 11.7 & 1.3 & 6 & 49 & 0.17 & 0 & 126 \\
\hline EH15 & October (2) & 22 & 8.4 & 724 & 52 & 28.0 & 100 & 135 & 276 & 73 & 6.9 & 21.6 & 11.2 & 1.4 & 6.3 & 41 & 0.14 & 4 & 131 \\
\hline EH16 & November (1) & 20.3 & 8.2 & 734 & 48 & 24.0 & 96 & 121 & 294 & 75 & 7.2 & 20.8 & 10.7 & 1.6 & 6.7 & 44 & 0.16 & 0 & 121 \\
\hline EH17 & November (2) & 18.7 & 8.1 & 752 & 45 & 22.0 & 92 & 128 & 268 & 80 & 7.4 & 20.4 & 10.0 & 1.3 & 6.4 & 46 & 0.18 & 2 & 126 \\
\hline EH18 & December (1) & 17 & 8.3 & 778 & 47 & 25.0 & 88 & 131 & 282 & 85 & 7.5 & 18.4 & 10.2 & 1.1 & 6 & 41 & 0.16 & 4 & 127 \\
\hline EH19 & December (2) & 16.4 & 8.4 & 760 & 49 & 23.0 & 97 & 134 & 236 & 77 & 7.7 & 20.4 & 11.2 & 1 & 5.7 & 50 & 0.17 & 4 & 130 \\
\hline EH20 & January (1) & 14.4 & 8.3 & 740 & 52 & 27.0 & 90 & 126 & 218 & 74 & 7.6 & 19.2 & 10.2 & 1 & 5.3 & 45 & 0.15 & 0 & 126 \\
\hline EH21 & January (2) & 15.5 & 8.2 & 728 & 48 & 25.0 & 86 & 122 & 210 & 69 & 7.2 & 16.8 & 10.7 & 0.8 & 5.2 & 38 & 0.16 & 0 & 122 \\
\hline
\end{tabular}

*All parameters are expressed in $\mathrm{mg} / 1$ except Temp., $\mathrm{pH}$ and EC. Temp. is expressed in ${ }^{\circ} \mathrm{C}$. EC is expressed in $\mu \mathrm{mhos} / \mathrm{cm}$.

Table.2 Quality Indices for sodium hazard

\begin{tabular}{|c|c|}
\hline Quality Index & Formula \\
\hline Sodium Adsorption Ratio (SAR) & $\mathrm{Na}^{+} /\left(\left(1 / 2\left(\mathrm{Ca}^{2+}+\mathrm{Mg}^{2+}\right)\right)^{1 / 2}\right)$ \\
\hline Percent Soluble Sodium (PSS) & $\mathrm{Na}^{+} /\left(\mathrm{Na}^{+}+\left(\mathrm{K}^{+}+\mathrm{Ca}^{2+}+\mathrm{Mg}^{2+}\right)^{*} 100\right.$ \\
\hline Exchangeable Sodium Percentage (ESP) & $=\left(100^{*}\left(0.01475^{*} \mathrm{SAR}-\right.\right.$ \\
\hline Residual Sodium Carbonate (RSC) & $0.0126)) /\left(1+\left(0.01475^{*} \mathrm{SAR}-0.0126\right)\right)$ \\
\hline
\end{tabular}

*All parameters used in formulae are in me/l units. 
Table.3

TABLE - 3 DATA ANALYSIS (ETP, SARAS)

\begin{tabular}{|c|c|c|c|}
\hline PARAMETERS & RANGE & MEAN & $\mathrm{CV}$ \\
\hline Temp. & $14.4-28.4$ & 21.8 & 0.20 \\
\hline pH & $7.9-8.8$ & 8.3 & 0.03 \\
\hline EC & $670-840$ & 741.5 & 0.05 \\
\hline COD & $45-84$ & 56.5 & 0.20 \\
\hline BOD & $22-44$ & 29.2 & 0.20 \\
\hline TH & $86-116$ & 96.0 & 0.08 \\
\hline $\mathbf{T A}$ & $121-148$ & 130.5 & 0.05 \\
\hline TDS & $210-354$ & 272.8 & 0.15 \\
\hline $\mathrm{Na}^{+}$ & $58-85$ & 71.3 & 0.10 \\
\hline $\mathbf{K}^{+}$ & $6-8.2$ & 6.9 & 0.09 \\
\hline $\mathrm{Ca}^{+2}$ & $16.8-24$ & 20.3 & 0.10 \\
\hline $\mathrm{Mg}^{+2}$ & $10-13.6$ & 11.0 & 0.08 \\
\hline $\mathrm{NO}_{3}^{-}$ & $0.8-1.8$ & 1.3 & 0.20 \\
\hline $\mathrm{SO}_{4}^{-2}$ & $5.2-6.8$ & 6.04 & 0.08 \\
\hline $\mathrm{Cl}^{-}$ & $37-50$ & 43.5 & 0.08 \\
\hline $\mathbf{F}$ & $0.1-0.18$ & 0.15 & 0.14 \\
\hline WWQI & $43.76-68.96$ & 51.12 & 0.13 \\
\hline PSS & $56.18 \%-65.31 \%$ & $59.44 \%$ & 0.04 \\
\hline ESP & $2.619-4.337$ & 3.285 & 0.12 \\
\hline AI & $11.961-12.987$ & 12.420 & 0.02 \\
\hline SAR & $2.678-3.928$ & 3.158 & 0.09 \\
\hline BOD/COD & $0.469-0.561$ & 0.517 & 0.05 \\
\hline LSI & $0.054-1.102$ & 0.427 & 0.68 \\
\hline RSC & $-0.029-0.478$ & 0.248 & 0.49 \\
\hline
\end{tabular}

Table.4 Quality Indices for corrosion potential

\begin{tabular}{|c|c|}
\hline Quality Index & Formula \\
\hline Langelier Saturation Index (LSI) & $\mathrm{pH}-(9.3+\mathrm{pHs})$ \\
\hline Aggressive Index (AI) & $\mathrm{pH}+\log (\mathrm{TH} * \mathrm{TA})$ \\
\hline
\end{tabular}

$* \mathbf{p H s}=(\log 10(\mathrm{TDS})-1) / 10)+(13.12 * \log 10(\mathrm{Temp} .+273)+34.55)-(\log 10(\mathrm{TH})-0.4)-\log 10(\mathrm{TA})$

\section{Langelier Saturation Index (LSI)}

Calculated values of LSI varied from 0.055to1.103with CV 68.0\% and overall value of0.427for all the analyzed samples. Data revealed nature of treated water from slight corrosion to slight scale with overall faint scale coating. Aggressive Index (AI): calculated values of AI for all the analyzed samples varied from 11.961 to 12.988 with $\mathrm{CV}$ only $2.0 \%$ and overall value of 12.420. Data reveals non-aggressive nature of corrosivity for all the treated water samples. Although information obtained from LSI and AI is not quantitative, it can be useful in estimating treatment requirements for low pressure boilers, cooling towers and waste treatment plants. The results of present study were analyzed from three aspects - irrigation water quality, environment pollution indicators and 
corrosive nature of treated effluent of SARAS dairy, Hanumangarh. All the measured parameters were within permissible range except BOD values of some samples. The results revealed that treated water was of good quality in terms of irrigation water quality parameters. Data indicated non-aggressive nature of the treated effluent with slight scales to slight corrosion. Overall, the ETP is efficient to produce treated water that may be used for irrigation, released to surface water bodies or may be used for other industrial purposes. Somewhat high BOD values must be regulated and requires micro biological analysis.

\section{Abbreviations}

SAR (Sodium Adsorption Ratio), PSS (Percent Soluble Sodium), ESP(Exchangeable Sodium Percentage), RSC(Residual sodium carbonate), EC (Electrical Conductivity), TDS (Total Dissolved Solids), BOD (biological oxygen demand), COD (Chemical Oxygen Demand), LSI (Langelier Saturation Index), AI (Aggressive Index).

\section{References}

American public health association, (APHA) Standard Methods for the Examination of Water and Wastewater, 23rd EditionWashington, DC, USA.

Ayers R. S. and Westcot D. W. 1994. Water Quality for Agriculture, Irrigation and Drainage Paper 29, Rev1, Food and
Agriculture Organization of the United Nations, Rome.

Bauder T A, Waskom R M, Sutherland P L, Davis J G (2011). Irrigation water quality criteria. Colorado State University Extension Publication, Crop series/irrigation. 0506, 4pp.

Chaudhary D. H. and Dhoble R. M. (2010), Performance evaluation of effluent treatment plant of dairy industry, Current World Environment Vol. 5(2), 373-378.

Environmental Guidelines for the dairy processing industry. Environment Protection Authority, June 1997.

FAO/UNESCO (1973) Irrigation, drainage and salinity. An International source book. Unesco/FAO, Hutchinson \& Co (Publishers) Ltd, London, 510 pp.

IS 2296 (1982): Tolerance limits of inland surface waters, Class-E.

IS-3025 (1987): Methods of Sampling and Test (Physical and Chemical) for water $\&$ waste water.

IS 11624 (1986): Guidelines for the quality of irrigation water.

Kolhe A. S. and Pawar V. P. 2011. Environmental Sciences Recent Res. in Sci. Technol., 3(5): 29-32.

Pearson G A (1960) Tolerance of crops to exchangeable sodium. USDA Information Bulletin.

Wilcox L V, Blair G Y, Bower C A (1954). Soil Science 77:259-266 No. 216, 4 pp.

\section{How to cite this article:}

Rinku Chawla and Atul Arora. 2021. An Evaluation of Treated Effluent Quality of Dairy Industry in Hanumangarh, Rajasthan, India. Int.J.Curr.Microbiol.App.Sci. 10(08): 414-420. doi: https://doi.org/10.20546/ijcmas.2021.1008.050 